\title{
PENINGKATKAN HASIL BELAJAR IPA MELALUI PENGGUNAAN METODE DEMONSTRASI PADA SISWA KELAS 4 SD
}

\author{
Fikria Trisnawaty \\ 292013149@student.uksw.edu \\ Program Studi PGSD \\ FKIP Universitas Kristen Satya Wacana \\ Slameto \\ slameto@staff.uksw.edu \\ Program Studi PGSD \\ FKIP Universitas Kristen Satya Wacana
}

\begin{abstract}
ABSTRAK
Penelitian ini dilatar belakangi oleh masalah berupa rendahnyahasil belajar IPA siswa kelas 4 SD Negeri Watu Agung 02 Tuntang Semester 2 tahun 2016/207 adalah 62,5\% siswa yang tuntas dan yang tidak tuntas 37,5\%. Rendahnya hasil belajar disebabkan karena siswa kurang aktif dan antusias pada saat proses pembelajaran serta metode mengajar yang digunakan guru masih konvensional. Penelitian tindakan kelas ini terdiri dari 2 siklus dan setiap siklusnya terdiri dari 3 pertemuan. Teknik analisis data yang digunakan adalah 3 teknik pengumpulan data, ketiga data tersebut adalah tes formatif, observasi, dan angket. Peningkatan hasil belajar kognitif yang terjadi yakni siswa yang sudah tuntas pada siklus I dan siklus II adalah $81,25 \%$ dan $93,75 \%$. Pada minat belajar IPA terjadi peningkatan sebesar 50\%. Berdasarkan hasil dari penelitian disarankan bagi siswa yang memiliki kemampuan akademis agar lebih dapat berbagi pengetahuan dengan rekannya yang lain dalam hal kerja kelompok. Selain itu, guru diharapkan dapat meningkatkan keterampilannya dalam menggunakan metode pembelajaran demonstrasi dalam rangka meningkatkan hasil belajar siswa, karena dalam implementasi metode demonstrasi dapat membantu siswa lebih aktif, lebih berminat dalam mengikuti kegiatan pembelajaran.
\end{abstract}

Kata kunci: hasil belajar, metode pembelajaran demonstrasi.

\section{PENDAHULUAN}

Pembelajaran dalam prosesnya akan melibatkan berbagai komponen, menurut Sugandi (2007: 28-30) komponen pembelajaran meliputi tujuan, subjek belajar, materi pembalajaran, strategi pembelajaran (metode, model, teknik mengajar), media pembelajaran, serta penunjang (fasilitas, buku sumber, alat pelajaran, bahan pelajaran). Komponen utama dalam sistem pembela- jaran adalah subyek belajar karena berperan sebagai subyek sekaligus obyek (Sugandi 2007: 29). Ada dugaan dalam praktik pembelajaran subyek belajar ini masih belum terlayani dengan baik.

Dari hasil observasi awal pada mata pelajaran IPA siswa kelas IV SD Negeri 02 Watu Agung Tuntang, penulis menemukan beberapa kesenjangan yang ada dalam proses pembelajaran. Kesenjangan utama yang ada 
pada proses pembelajaran yaitu tidak tercapainya KKM dengan nilai rata-rata 68 dan yang mencapai KKM 68 baru mencapai $62,5 \%$. selain itu penulis juga menemukan beberapa kesenjangan yang lain seperti dibawah ini: 1) Metode pembelajaran yang digunakan oleh guru masih menggunakan metode yang kurang mengaktifkan siswa. sehingga siswa masih banyak yang kurang memperhatikan. 2) Tidak ada siswa yang bertanya mengenai materi pelajaran pada saat guru menjelaskan. 3) Siswa kurang aktif dan antusias dalam mengikuti pelajaran. 4) Siswa terlihat bosan pada saat guru menerangkan di depan kelas.

Dari hasil observasi tersebut dapat disimpulkan bahwa metode pembelajaran yang digunakan masih kurang maksimal. Apabila kondisi tersebut dibiarkan berlarutlarut tanpa adanya tindakan untuk mengubah atau memperbaiki dikhawatirkan tujuan yang dicapai dalam pembelajaran kurang mengaktifkan siswa.

Penelitian ini bertujuan untuk: 1) Meningkatkan hasil belajar IPA siswa kelas IV melalui metode pembelajaran demonstrasi. 2) Mendeskripsikan langkah-langkah metode pembelajaran demonstrasi dalam meningkatkan hasil belajar IPA siswa kelas IV.

Manfaat yang diharapkan dalam penelitian ini adalah sebagai berikut: Manfaat Praktis 1) Bagi sekolah sebagai bahan pertimbangan untuk memperbaiki metode pembelajaran yang sufah ada dengan menggunakan metode pembelajaran demonstrasi ini. Dengan adanya metode pembelajaran yang beraga, diharapkan mutu pendidikan di sekolah meningkat. 2) Bagi guru diharapkan dengan metode pembelajaran baru ini dapat meningkatkan hasil belajar IPA siswa kelas IV Sebagai bahan pertimbangan dalam menggunakan metode pembelajaran yang tepat bagi siswa, sehingga mutu pembelajaran dapat meningkat. 3) Bagi siswa diharapkan penelitian ini dapat memberikan pengalaman dan kesan sebagai hasil pembelajaran dalam diri siswa.

\section{TINJAUAN PUSTAKA}

Pengertian pembelajaran telah dijelaskan dalam pasal 1 angka 20 UndangUndang No. 20 Tahun 2003 tentang Sistem Pendidikan Nasional yang menyatakan pembelajaran adalah proses interaksi peserta didik dengan pendidikan dan sumber belajar pada suatu lingkungan belajar. Proses pembelajaran harus didasarkan pada prinsip terjadinya interaksi secara optimal antara peserta didik dengan pendidik, peserta didik sendiri, serta peserta didik dengan aneka sumber belajar termasuk lingkungan (Miarso, 2007:154). Pembelajaran menurut Susanto (2013: 19) adalah bantuan yang diberikan pendidik agar terjadi proses perolehan ilmu dan pengetahuan, penguasaan, kemahiran, dan tabiat, serta pembentukan sikap dan keyakinan pada peserta didik.

Belajar adalah tingkah laku yang diubahmelalui latihan atau pengalaman (Ismail, 2016: 33). Tingkah laku yang mengalami perubahan karena belajar menyangkut berbagai aspek kepribadian, fisik maupun psikis, seperti perubahan dalam pengertian, pemecahan suatu masalah, keterampilan, kecakapan, kebiasaan atau sikap (Purwanto, 2002: 84).

\section{Metode Pembelajaran Demonstrasi}

Metode juga dapat diartikan sebagai cara. Sementara itu pengertian sederhana pembelajaran adalah proses interaksi antara guru dan siswa. Pembelajaran selalu identik dengan kegiatan belajar dan mengajar di sekolah. Tujuan pembelajaran itu sendiri adalah untuk mendapatkan ilmu. 
Pembelajaran pada hakikatnya adalah suatu kegiatan yang dilakukan oleh seorang guru sedemikian rupa sehingga tingkah laku siswa berubah ke arah yang lebih baik (Darsono, 2000: 24). Artinya metode pembelajaran adalah cara mengajar yang digunakan guru agar siswa memperoleh ilmu melalui proses interaksi di lingkungan sekolah, sehingga tingkah laku siswa berubah ke arah yang lebih baik.

Agar tujuan pembelajaran dengan metode demonstrasi dapat tercapai, dapat digunakan strategi yang dijelaskan oleh Huda (2013: 232) seperti berikut: 1) merumuskan dengan jelas jenis kecakapan atau keterampilan yang diperoleh setelah demonstrasi dilakukan; 2) menentukan peralatan yang digunakan, kemudian diuji coba terlebih dahulu agar pelaksanaan demonstrasi tidak mengalami kegagalan. 3. Menetapkan prosedur yang dilakukan, dan melalukan percobaan sebelum demonstrasi dilakukan. 4. Menentukan durasi pelaksanaan demonstrasi. 5. Memberikan kesempatan kepada siswa untuk memberikan komentar pada saat maupun sesudah demonstrasi. 6 . Meminta siswa untuk mencatat hal-hal yang dianggap perlu. 7. Menetapkan rencana untuk menilai kemajuan siswa.

Menurut Miftahul huda (2013: 230) bahwa keunggulan metode Demonstrasi sebagai: 1) Membuat pengajaran menjadi lebih jelas dan konkrit 2) Memusatkan perhatian 3) Lebih mengarahkan proses belajar siswa pada materi yang sedang dipelajari 4) Lebih melekatkan pengalaman dan kesan sebagai hasil pembelajaran dalam diri siswa. 5) Membuat siswa lebih mudah memahami apa yang dipelajari. 6) Membuat proses pengajaran lebih menarik. 7) Merangsang siswa untuk aktif mengamati dan menyesuaikan antara teori dengan kenyataan. 8) Membantu siswa memahami dengan jalannya suatu proses atau kerja suatu benda. 9) Memudahkan berbagai jenis penjelasan. 10) Memperbaiki kesalahan yang terjadi dari hasil ceramah melalui pengamatan dan contoh konkret dengan menghadirkan objek sebenarnya.

Adapun kelemahan seperti yang dikemukakan Huda (2013: 233) adalah sebagai berikut: 1) Mengharuskan keterampilan guru secara khusus. 2) Tidak tersedianya fasilitas-fasilitas pendukung, seperti peralatan, tempat, dan biaya yang memadai di setiap kelas. 3) Memerlukan kesiapan dan perencanaan yang matang disamping waktu yang cukup panjang. 4) Kesulitan siswa terkadang untuk melihat jelas benda yang akan dipertunjukkan. 5) Tidak semua benda dapat didemonstrasikan. 6) Sukar dimengerti bila didemonstrasikan oleh guru yang kurang menguasai materi atau barang yang didemonstrasikan. Mengingat ada kelemahan seperti itu peneliti menambah langkah-langkah pembelajaran demonstrasi yang dimodifikasikan dengan standar proses terdiri dari kegiatan awal, kegiatan inti (eksplorasi, laborasi, dan konfirmasi) dan kegiatan penutup.

Agar pelaksanaan metode demonstrasi dalam proses pembelajaran dapat berjalan dengan semestinya, Suprijono (2009: 149) menjelaskan langkah-langkah dalam melaksanakan metode demonstrasi sebagai berikut: 1) Guru menyampaikan kompetensi yang ingin dicapai. 2) Guru menyajikan gambaran sekilas materi yang akan dibahas. 3) Menyiapkan bahan atau alat yang diperlukan. 4) Menunjuk salah seorang siswa untuk mendemonstrasikan sesuai skenario yang telah disiapkan. 5) Seluruh siswa memperhatikan demonstrasi dan menganalisisnya. 6) Tiap siswa mengemukakan hasil analisanya dan juga pengalaman siswa didemonstrasikan. 7) Guru membuat kesimpulan. 


\section{Hasil Belajar}

Kegiatan akhir dalam pembelajaran adalah proses evaluasi yang bertujuan untuk mengetahui hasil belajar yang telah diperoleh siswa (Sulihaawati dkk, 2014: 7). Hasil belajar adalah kemampuan yang dimiliki siswa setelah ia menerima pengalaman (Sudjana, 2011: 22).

Faktor-Faktor yang Mempengaruhi Hasil Belajar Menurut Slameto (2010: 54) faktor-faktor yang mempengaruhi hasil belajar yaitu faktor intern dan faktor ekstern. Faktor-faktor intern meliputi: A. Faktor jasmani yaitu faktor kesehatan dan cacat tubuh. B. Faktor psikologi, yaitu 1) Intelegensi, Intelegensi besar pengaruhnya terhadap kemajuan belajar. 2) Perhatian, Untuk dapat menjamin hasil belajar yang baik, maka siswa harus mempunyai perhatian terhadap bahan yang dipelajarinya. 3) Minat, Minat besar pengaruhnya terhadap belajar, karena bila bahan pelajaran yang dipelajari tidak sesuai dengan minat siswa, siswa tidak akan belajar dengan sebaik-baiknya. 4) Bakat, Bakat itu mempengaruhi belajar. Jika bahan pelajaran yang dipelajari siswa sesuai dengan bakatnya, maka hasil belajarnya lebih baik. 5) Motif, Dalam proses belajar haruslah diperhatikan apa yang dapat mendorong siswa agar dapat belajar dengan baik 6) Kematangan, Kematangan adalah suatu tingkat/fase dalam pertumbuhan seseorang 7) Kesiapan, Kesiapan adalah kesediaan untuk memberi respon atau bereaksi. C. Faktor kelelahan, Kelelahan pada seseorang walaupun sulit untuk dipisahkan, tetapi dapat dibedakan menjadi dua macam, yaitu kelelahan jasmani dan kelelahan rohani. Agar siswa dapat belajar dengan baik haruslah menghindari jangan sampai terjadi kelelahan dalam belajarnya. Sehingga perlu diusahakan kondisi yang bebas dari kelelahan. Adapun faktor eksternal meliputi: faktor keluarga, faktor sekolah, faktor masyarakat.

\section{METODE}

Penelitian ini termasuk penelitian tindakan kelas (PTK). Jenis PTK yang digunakan adalah kolaboratif dimana peneliti bekerjasama dengan ppihak terkait yang dalam hal ini adalah guru kelas IV SD Negeri Watu Agung 02 Tuntang. Tujuan PTK adalah untuk memperbaiki dan meningkatkan proses belajar mengajar di kelas. PTK terdiri dari empat kagiatan yakni perencanaan (planning), pelaksanaan (implementation), observasi (observation), dan refleksi (reflection). Variabel Bebas variabel bebas adalah berdiri sendiri. Variabel bebas dalam penelitian ini adallah metode demonstrasi. Secara garis besar metode pembelajaran demonstrasi merupakan metode pembelajaran yang menunjukkan atau mencontohkan kepada siswa suatu proses terjadinya peristiwa atau benda yang diperagakan oleh guru.Variabel Terikat, variabel ini tidak dapat berdiri sendiri. Dalam penelitian ini variabel terikat adalah hasil belajar IPA siswa kelas IV SD Negeri Watu Agung 02 Tuntang.

Hasil belajar didapat siswa setelah mengalami proses pembelajaran. Dalam penelitian tindakan kelas ini, hasil belajar siswa kelas IV SD Negeri Watu Agung 02 Tuntang dijaring melalui pretest dan postest di setiap siklusnya menggunakan soal pilihan ganda. Ketuntasan perolehan nilai diukur dengan KKM.

Pada penelitian ini terdapat tiga teknik pengumpulan data. Ketiga data tersebut adalah tes formatif, observasi, dan angket. Instrumen pengumpulan data yang digunakan dalam penelitian ini adalah: 1). Butir Soal Tes 2). Lembar Observasi 3). Lembar Angket. Indikator kinerja merupakan harapan meningkatnya pemahaman dan hasil belajar 
siswa berdasarkan kenaikan nilai rata-rata di kelas dari siklus 1 ke siklus 2. Penggunaan metode pembelajaran demonstrasi dinyatakan dapat meningkatkan hasil belajar siswa apabila $80 \%$ dari jumlah siswa mendapat nilai $\geq$ KKM.

Teknik Penyajian DataTeknik analisis data yang digunakan dalam penelitian ini adalah dengan cara mendetailkan kenaikan rata-rata hasil belajar dari ranah kognitif, afektif dan psikomotorik untuk mengetahui selisih peningkatan nilai hasil belajar antar siklus. Hasil belajar kognitif didapat dari hasil tes formatif yang diberikan pada pretest (sebelum tindakan) dan postest pada setiap siklusnya, hasil belajar afektif dinilai dari aspek kemampuan siswa dalam hal mempresentasikan dan pasikomotorik dilihat dari aspek keterampilan menggunakan alat dan bahan yang digunakan untuk mendemonstrasikannya.

\section{HASIL PENELITIAN DAN PEMBA- HASAN}

\section{Deskripsi Hasil}

Berdasarkan observasi tahap awal atau sebelum dilakukannya tindakan, hasil belajar IPA siswa kelas IV SDN WATU AGUNG 02 TUNTANG mengalami ketidaktuntasan. Siswa yang dengan nilai tuntas dan memenuhi KKM sebanyak 10 siswa dengan presentase $62,5 \%$. Sedangkan siswa dengan nilai kurang dari KKM sebanyak 6 siswa dengan presentase $37,5 \%$.

Hasil belajar kognitif siswa pada siklus 2 lebih baik dari pada siklus 1 . Hal tersebut dapat dilihat pada tabel 4.6 yang menggambarkan bahwa nilai rata-rata hasil belajar siswa pada siklus 1 adalah 74,75 dan siklus 2 adalah 87,31.

Tabel 1 Hasil Belajar Kognitif Siswa

\begin{tabular}{cccccccc}
\hline \multirow{2}{*}{ No. } & \multirow{2}{*}{ Ketuntasan Belajar } & \multicolumn{2}{c}{ Kondisi Awal } & \multicolumn{2}{c}{ Siklus 1 } & \multicolumn{2}{c}{ Siklus 2 } \\
\cline { 3 - 8 } & & $\begin{array}{c}\text { Jumlah } \\
\text { Siswa }\end{array}$ & $\begin{array}{c}\text { Presentase } \\
(\boldsymbol{\%})\end{array}$ & $\begin{array}{c}\text { Jumlah } \\
\text { Siswa }\end{array}$ & $\begin{array}{c}\text { Presentase } \\
(\mathbf{\%})\end{array}$ & $\begin{array}{c}\text { Jumlah } \\
\text { Siswa }\end{array}$ & $\begin{array}{c}\text { Presentase } \\
(\boldsymbol{\%})\end{array}$ \\
\hline 1. & Tuntas & 10 & 62,50 & 13 & 81,25 & 15 & 93,75 \\
2. & Belum Tuntas & 6 & 37,50 & 3 & 15,75 & 1 & 6,25 \\
\hline & Jumlah & 16 & 100 & 16 & 100 & 16 & 100 \\
\hline
\end{tabular}

Berdasarkan tabel 1 di atas dapat dikatakan bahwa hasil belajar siswa kelas IV SDN WATU AGUNG 02 TUNTANG siklus I ketuntasan belajar siswa sebanyak 13 siswa dengan presentase sebesar $62,50 \%$. Kemudian 3 siswa dengan nilai yang belum tuntas sebanyak 3 siswa dengan prosentase sebesar 37,50\%.

Hasil analisis deskriptif ini juga menunjukkan bahwa masih terdapat 3 siswa yang masih perlu mendapat perhatian lebih dalam peningkatan hasil belajar. Peningkatan hasil belajar kognitif berada pada siklus 2, dapat dilihat pada tabel di atas ketuntasan belajar siswa pada siklus 2 sebanyak 15 siswa dengan presentase sebesar $62,50 \%$. Kemudian 1 siswa yang dengan nilai yang belum tuntas dengan prosentase sebesar 6,25\%. Dengan demikian dapat dikatakan bahwa hasil belajar IPA siswa kelas IV SDN WATU AGUNG 02 TUNTANG mengalami peningkatan dari siklus 1 ke siklus 2 sebanyak 3 siswa dengan presentase kenaikan sebesar $17 \%$.

Data minat belajar didapat dari hasil pengamatan selama proses pembelajaran melalui metode demonstrasi berlangsung. Adapun hasil belajar afektif siswa didapat dari kemampuan berdiskusi siswa dan kemampuan mempresentasikan yang dimiliki siswa. 
Tabel 2 Data Minat Belajar IPA

\begin{tabular}{ccc}
\hline \multirow{2}{*}{ Siklus } & \multicolumn{3}{c}{ Rerata Minat Belajar IPA } \\
\cline { 2 - 3 } & Jumlah Siswa yang berdiskusi (\%) & Persentase (\%) \\
\hline Siklus 1 & $8(50)$ & $7(44)$ \\
Siklus 2 & $16(100)$ & $15(94)$ \\
\hline
\end{tabular}

Dari tabel di atas, memberikan makna bahwa hasil belajar afektif siswa pada pelaksanaan diskusi dan presentasi menunjukkan adanya peningkatan. Pada siklus 1, presentase hasil belajar afektif siswa untuk aspek diskusi sebanyak $50 \%$ dan presentasi sebesar $44 \%$. Selanjutnya, pada siklus 2 terjadi peningkatan hasil belajar afektif siswa untuk aspek diskusi menjadi $100 \%$ dan presentasi sebesar $94 \%$. Artinya, melalui metode demonstrasi, siswa akan merasakan suasana baru dalam kelas dan menjadikan siswa lebih aktif dan antusias dalam mengikuti pembelajaran.

\section{Pembahasan}

Berdasarkan hasil observasi sebelum tindakan pada siswa kelas IV SD Negeri Watu Agung 02 Tuntang menyatakan bahwa hasil belajar siswa mata pelajaran Ilmu Pengetahuan Alam (IPA) melalui metode demonstrasi, siswa akan merasakan suasana baru dalam kelas dan menjadikan siswa lebih aktif dan antusias dalam mengikuti pembelajaran.

\section{Siklus 1}

Pada siklus 1 melalui penerapan pembelajaran dengan metode demonstrasi pada mata pelajaran IPA di kelas IV SD Negeri Watu Agung 02 Tuntang terjadi peningkatan yaitu sebesar $62,50 \%$ siswa tuntas dengan jumlah 10 siswa dan 6 siswa tidak tuntas atau dengan prosentase sebesar $37,50 \%$.

\section{Siklus 2}

Ketuntasan belajar siswa pada siklus 2 sebanyak 15 siswa dengan presentase sebesar $62,50 \%$. Kemudian 1 siswa yang dengan nilai yang belum tuntas dengan prosentase sebesar 6,25\%. Dengan demikian dapat dikatakan bahwa hasil belajar IPA siswa kelas IV SDN WATU AGUNG 02 TUNTANG mengalami peningkatan dari siklus 1 ke siklus 2 sebanyak 3 siswa dengan presentase kenaikan sebesar 12,50\%. 3. Hasil Belajar Afektif Siswa, hasil belajar afektif siswa pada saat pelaksanaan diskusi dan presentasi menunjukkan adanya peningkatan. Pada siklus 1, presentase hasil belajar afektif siswa untuk aspek diskusi sebanyak $50 \%$ dan presentasi sebesar $44 \%$. Selanjutnya, pada siklus 2 terjadi peningkatan hasil belajar afektif siswa untuk aspek diskusi menjadi $100 \%$ dan presentasi sebesar 94\%. Artinya melalui metode Demonstrasi, siswa akan merasa suasana baru dalam kelas dan menjadi lebih aktif dan antusias dalam mengikuti pembelajaran. 4. Hasil Belajar Psikomotorik Siswa hasil belajar psikomotorik siswa pada siklus 1 , ketrampilan siswa menggunakan peralatan masih dalam kategori kurang baik.namun pada siklus 2 hasil belajar psikomotorik siswa meningkat dan dikategorikan baik.

Berdasarkan dari pembahasan tersebut, maka dapat disimpulkan bahwa pembelajaran melalui metode demonstrasi pada materi "Energi dan Penggunaannya" kelas IV SDN Watu Agung 02 Tuntang mengalami peningkatan hasil belajar siswa. Melalui penerapan metode demonstrasi siswa terlibat dan menjadi lebih aktif dalam mengikuti pembelajaran, menguasai materi, memiliki ketelitian dan kecermatan, serta mempunyai daya tangkap yang baik. 
Dengan metode demonstrasi siswa lebih mudah dalam menguasai materi karena siswa harus lebih teliti dan cermat dalam mengamati setiap langkah-langkah yang ada selama kegiatan demonstrasi berlangsung.

Karena dalam penelitiannya terbukti bahwa terdapat peningkatan hasil belajar siswa dengan menggunakan metode pembelajaran demonstrasi. Hasil penelitian ini mempunyai perbedaan dengan penelitian yang dilakukan antara peneliti sebelumnya dengan penelitian ini, perbedaannya adalah peneliti sebelumnya hanya menggunakan langkah-langkah metode pembelajaran demonstrasi saja tanpa menambah standar proses dalam penerapannya dan terdapat pembelajaran yang sesuai dengan eksplorasi, elaborasi dan konfirmasi.

Hal ini sejalan dengan penelitian yang dilakukan oleh: Erhan Rizky dkk (2012), Subrata (2016), Lina Amelia dan Teuku Nailul Munadi (2016), Susilorini (2015), Suparman Sade dan Tirta Maulana (2014), Supriyanto (2017), dan Nunung Sulistyaningsih (2013).

Dengan adanya penelitian ini memberikan implikasi teoritis yaitu setelah membandingkan metode pembelajaran Demonstrasi dengan penelitian sebelumnya adalah sejalan dan saling melengkapi diharapkan penelitian ini dapat memberikan sumbangan pengetahuan tentang pembelajaran inovatif dalam rangka meningkatkan hasil belajar dan mendeskripsikan langkah-langkah metode pembelajaran demonstrasi dalam meningkatkan hasil belajar IPA.

\section{SIMPULAN}

Berdasarkan hasil penelitian dan pembahasan, maka peneliti menyimpulkan sebagai berikut: Penelitian tindakan kelas (PTK) yang dilaksanakan pada tanggal 24 dan 25 maret 2017 terhadap siswa kelas IV Semester 2 SD Negeri Watu Agung 02 Tuntang melalui metode pembelajaran demonstrasi dapat meningkatkan hasil belajar siswa. Hal tersebut dibuktikan dengan meningkatnya hasil belajar siswa. Peningkatan hasil belajar kognitif yang terjadi yakni siswa yang sudah tuntas pada siklus I dan siklus II adalah 81,25\% dan 93,75\%. Pada minat belajar IPA terjadi peningkatan sebesar $50 \%$.

\section{DAFTAR PUSTAKA}

Darsono, Max. 2000. Teori Belajar dan Pembelajaran. Semarang: IKIP.

Erhan Rizki Aprian dkk. 2012. Upaya Meningkatkan Hasil Belajar Mata Pelajaran ilmu Pengetahuan Alam Melalui Metode Demontrasi

Huda Miftahul. 2013. Model-Model Pengajaran dan Pembelajaran. Yogyakarta: Pustaka Pelajar.

Ismail. 2016. Edukasi: Diagnosis Kesulitan Belajar Siswa Dalam Pembelajaran Aktif di Sekolah. Aceh: jurnal UIN Ar-Raniry Banda Aceh, 2 (1): 33

Miarso, Yusufhadi. 2007. Menyemai Benih Teknologi Pendidikan. Kencana Prenada Media Group: Jakarta.

Nunung Sulistianingsih. 2013. Meningkatkan Prestasi Belajar IPA Melalui Metode Demonstrasi Pada Siswa Kelas V SD Bogo Wijirejo Pandak Bantul Tahun Pelajaran 2013/2014.

Purwanto M. Ngalim, 2002. Psikologi Pendidikan, Bandung: Remaja Rosdakarya, 
Slameto. 2010. Belajar dan Faktor-faktor Yang Mempengaruhinya. Jakarta: PT. Rineka Cipta

Subrata. 2016. Penerapan Metode Demonstrasi Pada Materi Asam Basa Garam Untuk Meningkatkan Aktivitas dan Hasil Belajar Peserta Didik. Jurnal Scientia Indonesia, 1 (7): 28

Sudjana, Nana. 2011. Penilaian Hasil Proses Belajar Mengajar. Bandung: PT Remaja Rosdakarya.

Sulihawati dkk. 2014. Peningkatan Aktivitas dan Hasil Belajar Melalui Model Pembelajaran Kreatif Produktif. Bandar Lampung: jurnal FKIP Universitas Lampung.3 (10): 32
Sugandi, Achmad, 2007. Teori Pembelajaran. Semarang: UPT UNNES Press.

Suparman Sade dan Tirta Maulana. 2014. Upaya Meningkatkan Hasil Belajar Renang Gaya Dada Melalui Metode Demonstrasi. Jurnal Motion, 5 (1): 3

Suprijono Ahmad. 2009. Cooperative Learning, Teori dan Aplikasi Paikem. Yogyakarta: Pustaka Belajar.

Supriyanto. 2017. Peningkatan Prestasi Belajar Sumber Daya Alam Melalui Metode Demonstrasi Siswa Kelas 4 SD. Jurnal Riset dan Konseptual, 2 (1): 35

Susanto Ahmad. 2013. Teori Belajar dan Pembelajaran di Sekolah Dasar. Jakarta: Prenadamedia Group. 